\title{
CONTINGENCY DAN PENGARUH MODERATING VARIABEL
}

\author{
Michelle Veren Mosse
}

michellemosse02@gmail.com

Teori contingency menjelaskan tentang kepemimpinan dengan berdasarkan pada situasi organisasi dan kepemimpinan. Tidak semua organisasi dapat bertahan dengan gaya kepemimpinan dengan kondisi atau situasi tertentu. Teori contingency lebih menekankan pada kepribadian seorang pemimpin dan situasi yang dihadapi. Pendekatan ini lebih mengartikan bahwa tidak ada satupun gaya kepemimpinan entah dari sifat dan perilaku apapun yang akan cocok dengan semua situasi. Masing-masing situasi membutuhkan pemimpin dengan gaya kepemimpinan dengan sifat tertentu. Contingency teory menjelaskan tentang dasar-dasar perusahaan atau manajemen suatu perusahaan dengan bersifat umum karena setiap organisasi atau perusahaan memiliki karakteristik dan berada dalam kondisi ataupun situasi yang berbeda-beda. Teori ini membantu para pemimpin dengan potensial tertentu dalam mnilai sebuah situasi yang cocok dengan gaya kepeimpinan dan perilaku mereka.

Teori kontingensi merupakan suatu teori yang cocok digunakan dalam hal yang mengkaji reka bentuk, perancangan,prestasi dan kelakuan organisasi serta kajian yang berkaitan dengan pengaturanstrategik. Menurut Raybun dan Thomas (1991) dalam Azli dan Azizi (2009), teorikontingensi menyatakan pemilihan sistem akuntansi oleh pihak manajemen adalahtergantung pada perbedaan desakan lingkungan perusahaan. Pada tahap ini teorikontigensi bukanlah semata-mata sebuah teori namun lebih sebagai alat untukmemfasilitasi kita untuk memahami aliran situasi dari suatu kejadian dan memberi alternatif kepada organisasi atau individu untuk merespon aliran tersebut. Teori ini penting sebagai media untuk menerangkan perbedaan dalam struktur organisasi dan merupakan faktor yang sangat penting dalam menentukan pencapaian tujuan yang telah ditetapkan oleh organisasi. Kepemimpinan merupakan titik sentral dan penentu kebijakan dari kegiatan yang akan dilaksanakan dalam organisasi. Studi kepemimpinan jenis ini memfokuskan perhatiannya pada kecocokan antara karakteristik watak pribadi pemimpin,tingkah lakunya dan varibael-variabel situasional. Variabel yang sering dipakai dalam bidang ini adalah organisasi, lingkungan, teknologi, cara pembuatan keputusan , 
ukuran perusahan, struktur, strategi, dan budaya organisasi (Raybun dan Thomas, 1991) dalam Azli dan Azizi (2009), serta ketidakpastian, teknologi,industri, misi dan strategi kompetitif, observabilitas.

Variabel mediator adalah Variabel yang menjadi penghubung antara variable dependen ddan variable independen. Keberadaan variable mediator ini sangat berpengaruh untuk melihat besar atau tidaknya hubungan antara independen dan dependen variable.

Variable mediator yang menjelaskan tentang contingency contohnya jika dalam jurnal pratono 2018 "Does firm performance increase with risk-taking behavior under information technological turbulence". Dikataakan bahwa perilaku pengambiilan resiko berdampak positif terhadap kinerja perusahaan.. Hal ini dipengaruhi oleh kemampuan dari pelaku pengambilan resiko dalam membuat keeputusan mengambil resiko dan tingkah lakunya dalam bekerja, kemampuan penetapan harga. Dan pada jurnal Pratono, A.H. (2016), Strategic orientation and information technological turbulence: contingency perspective in SMEs, Business Process Management Journal, Hipotesis satu menyatakan bahwa Orientasi strategis memiliki pengaruh langsung terhadap kinerja perusahaan. Yang menjadi variable mediatornya adalah turbulensi lingkungan yaitu pengaruh social yang mempengaruhi bagian pemasaran dan informasi-informasi mengenai jaringan pelanggan dan Turbulensi Teknologi Informasi yang membantu pengembangan produksi dan pemasaran.

Pada jurnal Pratono (2018) Does Entrepreneurial Autonomy Foster SME Growth Under Technological Turbulence? The Empirical Evidence from Indonesia, Turbulensi teknologi memberikan efek moderasi pada hubungan antara kewirausahaan otonomi dan kinerja perusahaan. Menurut teori pemrosesan informasi, mekanistik atau pendekatan direktif harus bekerja dengan baik dalam situasi yang tenang. Manajer cenderung memiliki pengalaman dan pengetahuan yang diperlukan untuk mengembangkan strategi, pedoman, dan prosedur yang baik (Chen, Neubaum, Reilly, \& LynnChen et al. 2015).

Teknologi telah diakui untuk menyediakan produk yang berlimpah peluang pengembangan (Schilke 2014). Turbulensi lingkungan yang rendah memungkinkan perusahaan untuk memprediksi preferensi lingkungan, memanfaatkan inovasi baru, dan mengambil lebih banyak risiko (Pratono dan Mahmood 2015).

Mediating Effect adalah hasil yang merupakan pengaruh dari variabel mediator. Pada jurnal Pratono,. (2019), "Achieving sustainable competitive advantage through green entrepreneurial orientation and market orientation, Hipotesis satunya menyatakan 
Perusahaan yang berorientasi pasar dapat memperoleh manfaat dari dampak positif pada keunggulan kompetitif dengan mengintegrasikan kegiatan keberlanjutan mereka ke dalam strategi bisnis mereka (Pantouvakiset al., 2017). Kolaborasi antara dua organisasi atau lebih diyakini dapat menumbuhkan pembelajaran dan pengetahuan organisasi (Eirizet al., 2017), yang memimpin perusahaan untuk menghasilkan nilai ekonomi dari kemitraan yang berjalan dengan organisasi lain (Pouwels dan Koster, 2017). Hal ini menunjukkan kapabilitas perusahaan untuk memanfaatkan pengetahuan sebagai sumber daya berharga yang dibawa ke perusahaan (van Winkelen, 2010). Yang menjadi variable moderatingnya adalah Kemampuan tenaga kerja dan Sumber Daya Manusia dalam menyerap pengetahuan sangat penting untuk pembelajaran antar-organisasi. Hal inilah yang mendorong perusahaan untuk memperoleh, mengasimilasi, dan menerapkan pengetahuan eksternal. Karena orientasi pasar memungkinkan perusahaan untuk menanggapi intelijen pasar yang berkaitan dengan kebutuhan pelanggan (Morganet al., 2009), perusahaan mendapatkan umpan balik dari pelanggan yang memainkan peran penting untuk meningkatkan penelitian dan pengembangan. Inilah yang menjadi mediating effect. 
Pratono, A.H. (2016), Strategic orientation and information technological turbulence: contingency perspective in SMEs, Business Process Management Journal, 22(2). https://doi.org/10.1108/BPMJ-05-2015-0066

Pratono, A.H. (2018), Does firm performance increase with risk-taking behavior under information technological turbulence? Empirical evidence from Indonesian SMEs", Journal of Risk Finance, 19(4), 361-378. https://doi.org/10.1108/JRF-10-2017-0170

Pratono, A.H., Ratih, R.V.S. \& Arshad, D. (2018) Does Entrepreneurial Autonomy Foster SME Growth Under Technological Turbulence? The Empirical Evidence from Indonesia. Journal of Technological Behaviour Science 3, 170-178 . https://doi.org/10.1007/s41347-018-0051-9

Pratono, A.H., Darmasetiawan, N.K., Yudiarso, A. and Jeong, B.G. (2019), "Achieving sustainable competitive advantage through green entrepreneurial orientation and market orientation: The role of inter-organizational learning", The Bottom Line, Vol. 32 No. 1, pp. 2-15.

Pratono, A.H. (2018), "From social network to firm performance: The mediating effect of trust, selling capability and pricing capability", Management Research Review, Vol. 41 No. 6, pp. 680-700. 